\title{
The Association between Corporate Social Responsibility Disclosure and Tax Avoidance: Evidence from Philippines
}

\author{
Eko Budi Santoso ${ }^{*}$, Kezia Laturette ${ }^{2,}$ and Stanislaus Adnanto Mastan ${ }^{3}$ \\ ${ }^{1,2,3}$ Universitas Ciputra, Surabaya, Indonesia
}

\begin{abstract}
.
Social responsibility is an interesting topic, as it plays an important part in a company's strategy to increase its value in the eyes of its investors. By increasing its awareness on social responsibility, corporate has disclosed responsible activities to receive a recognition as an ethically responsible company in its business practices. However, some researchers conducted in developing countries show that social responsibility disclosure can act as a tool to deceive corporate financial fraud behaviour. Thus, this study aims to examine whether companies that actively disclose their social responsibility also behave ethically in their financial aspects. Specifically, this study investigates whether companies with good social responsibility also behave responsibly in the aspect of taxation by reducing the rate of tax avoidance practices. The sample group includes go public companies listed in the Philippine stock exchange during the period of 2014-2019 that published sustainability reporting. The results of this study show that corporate social responsibility has a negative association with tax avoidance.
\end{abstract}

Keywords:) CSR disclosure, tax aggressiveness, business ethics

\section{Introduction}

The issue of social responsibility starts from the increasing public awareness of the importance of companies in the society. This has led to the emergence of the triple bottom line concept (Elkington, 1998), which states that companies should not only focus on bottom line, namely profit (economic), but also pay attention to other bottom lines, namely planet (environmental) and people (social impact). Thus, regulators issued a regulation for companies that are actively involved in socially responsible activities. Companies have begun to actively conduct socially responsible activities, as well as disclose it as a form of accountability to the public. Non-governmental organisations, such as Global Reporting Initiatives, issue guidelines and standards to disclose social responsibility action, even though the disclosure is still voluntary.

Thus, the public gives appreciation to companies that actively conduct corporate social responsibility and label those companies as companies that behave ethically in their business practices. Few studies also show that companies that actively conduct and disclose social 


\title{
$11^{\text {th }}$ International Conference on Modern Research in
} MANAGEMENT, ECONOMICS and ACCOUNTING

\author{
18-20 December, 2020 Oxford, United Kingdom
}

responsibility benefit from a positive impact by showing increased company performance through sales growth, increased sales prices and better company value (Orlitzky et al., 2003; Blazovich and Smith, 2010; Lev et al., 2010; Harjoto and Jo, 2011; Wang, 2011).

However, it also shows that social responsibility disclosure can be used as a tool to increase the company's profits, which at some point will contradict its ethical business principles. Several researches show that corporates' motivation in disclosing their social responsibility is not always based on the company's ethical behaviour (Ling \& Sultana, 2015; Grougiou et al., 2016; Hemingway \& Maclagan, 2004). Specifically, Sikka (2010) states that companies that provide information about their promises and achievements related to their socially responsible behaviour are then proven to have manipulated taxation. This means that companies that actively carry out social responsibility activities cannot necessarily be categorised as companies that behave ethically in their business activities. Opportunistic managers can use social responsibility disclosure as a tool to deceive or distract shareholders from corporate tax avoidance behaviour.

The results of studies on the relationship between social responsibility disclosure and tax avoidance are inconclusive. Studies conducted by Hoi et al. (2013) and Lanis \& Richardson (2012) show a negative result, while another study conducted by Richardson (2008) shows a positive result. These findings indicate that there are certain contexts that affect the relationship between the two. This study uses an insurance on social responsibility disclosure as a moderating variable in finding the relationship between social responsibility disclosure towards tax avoidance. The context of this study focuses on Philippines as a developing country which, on one hand, has a high dependence on high taxation, but the country's revenue from taxation is considerably low. On the other hand, there is an increase in social responsibility disclosure. Developing countries are often dominated by opportunistic managers due to the weak protection for investors, so the managers can use social responsibility disclosure as a tool to cover their opportunistic behaviours

\section{Literature Review}

\subsection{Disclosure of Social Responsibility}

The underlining idea of corporate social responsibility is an embodiment of ethical business practices of the company (Bowen, 1953; Carroll, 1997). Companies that are actively carrying out socially responsible activities show their effort to improve the welfare with the shareholders, and the company also pays attention to the environment and the society. This also means that the company is responsible for having ethical business practices on the three bottom lines so that transparency in financial reporting and taxation becomes a part of corporate social responsibility behaviour (Atkins, 2006; Goel, 2010). Social responsibility should cover all areas of the company, including their financial aspect. This is in line with ethical theory, which states that companies should refer to their moral values where to fulfil their obligations to the stakeholders; companies should always refer to moral values (Garriga \& Mele, 2004). Companies that can do these well will likely attain superior long-term performances. 


\title{
$11^{\text {th }}$ International Conference on Modern Research in MANAGEMENT, ECONOMICS and ACCOUNTING
}

\author{
18-20 December, 2020 Oxford, United Kingdom
}

However, during its development, problems may occur when the bottom line is not seen as a complete unit. Social responsibility will only be about company' awareness on environmental issue and social impact, without seeing that corporate financial management also takes part in the social responsibilities. With the presence of empirical evidence showing that social responsibility disclosure influences business performance, companies can use their compassion on environment and social issues to improve the welfare of the company's owners. Social responsibility activities can be a legitimation for a company to continue its business, regardless of whether the business operations, including managing its finance, are in accordance with the ethical principles. This is also supported by naturalistic fallacy in the society, which states that something good means that it is right. When companies are actively disclosing their social responsibility (good), it means that the company has acted in an ethical manner in all its business practices (right). This condition can be exploited by opportunistic managers by carrying out social responsibility that aims to deceive stakeholders into its business actions on tax avoidance.

Social responsibility disclosure has also shifted from its original purpose of reflecting the company's ethical behaviour to be a tool of the company's strategy to gain profit. Companies use social responsibility disclosure as a tool to shape their image as an institution that is responsible for their business practices. Social responsibility is seen as a competitive advantage in facing business competition. Finally, the company will make a social responsibility disclosure based on the consideration that the disclosure will contribute to generating company profits and is not based on ethical considerations. Social responsibility disclosure becomes a tool to meet the stakeholders' expectations so the companies can continue to run their businesses. In the case of opportunistic managers, social responsibility disclosure is conducted to meet the expectations as a company that cares for the society. By leveraging the naturalistic fallacy, companies can gain superior short-term benefits, but can be counterproductive in the long run.

\subsection{Tax Avoidance}

Tax expense is one of the most significant expenses that affects the profits of a company. Thus, companies will always have the tendency to reduce their expenses. Regulators also understand this situation by giving incentives and loopholes in tax regulations to provide options in the companies' efforts to minimise the amount of tax to be paid, as long as they are within the legal corridor. However, the efforts will be considered as tax evasion when it hits the grey area and potentially violate taxation rules (Watson, 2015; Lietz, 2013).

In this study, tax avoidance is considered as an unethical act because it has an opportunistic nature and can potentially violate the applicable regulations. Tax avoidance act is a deliberate action by taxpayers who wish to minimise the amount of tax to be paid; moreover, their intention is not in compliance with the tax rules. For a country, tax avoidance causes the country to suffer losses that were not previously considered due to its tendency of violating the regulations. For companies, tax avoidance puts them at risk of receiving tax sanctions and can damage the companies' reputation. Tax avoidance practices tend to flare in developing countries because they have low investors' protection and weak tax infrastructure, thus opportunistic managers have more flexibility to take tax avoidance actions. 


\title{
$11^{\text {th }}$ International Conference on Modern Research in
}

MANAGEMENT, ECONOMICS and ACCOUNTING

\author{
18-20 December, 2020 Oxford, United Kingdom
}

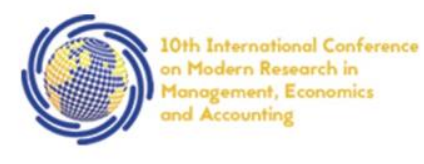

\subsection{Hypothesis Development}

Past studies found that a company's motivation to carry social responsibility disclosure is not always based on ethical consideration. Social responsibility disclosure that can lead to naturalistic fallacy within the society and can be used as a tool to deceive the society against unethical corporate actions. Companies can have social responsibility disclosure so that they can be considered as companies that act with ethical manners, even though the action is done to hide tax avoidance, which reflects an unethical action by the company. This situation can grow in developing countries due to a weak legal system and a low protection towards investors (Ling \& Sultana, 2015). A study by Preuss (2010) found that companies that practice tax avoidance tend to be active in disclosing their social responsibility. This result is also supported by a study from David et al., (2015) which found a positive correlation between social responsibility disclosure and tax avoidance. Based on the information above, the research hypothesis is developed as follows:

H1 : Social responsibility disclosure is positively associated with tax avoidance

\section{Research Method}

This study is conducted on go public companies listed on the Philippine Stock Exchange (PSE). The research samples include companies that published sustainability reporting based on Global Reporting Initiative (GRI) in the period of 2014-2019. Social responsibility disclosure is measured by the disclosure index that was created based on a combination of the GRI G4 index and GRI Standard index. During the research period, GRI published the G4 guidelines (2013) and the GRI standards (2016).

Based on the two rules mentioned, the researcher creates a disclosure index that will be used to measure the social responsibility disclosure variable. Social responsibility disclosure is measured by comparing the number of disclosure items reported by the company and the disclosure index. The tax avoidance variable is proxied by GAAP ETR (Dhaliwaal et al, 2004) that is measured by dividing the total income tax expenses by the company's profit before tax. The higher the GAAP ETR value, the lower the tax avoidance measures are. This study uses control variables, which are companies (Prior et al., 2008), Profitability (Desai and Dharmapala, 2006), level of debt (Lanis and Richardson, 2015) and capital intensity ratio (Mohanadas et al, 2019). The research model used to test the hypothesis is as follows:

$$
G A A P_{-} E T R_{i t}=\alpha_{0}+\alpha_{1} C S R I_{i t}+\alpha_{2} S I Z E_{i t}+\alpha_{3} R O E_{i t}+\alpha_{4} L E V_{i t}+\alpha_{5} C I R_{i t}+\varepsilon_{i t}
$$

\section{Result and Discussion}

Based on the study period and the availability of data needed to measure the research variables, the study obtains a final sample of 113 observations from 39 companies. The following table is a descriptive statistic from the sample group: 
$11^{\text {th }}$ International Conference on Modern Research in

MANAGEMENT, ECONOMICS and ACCOUNTING

\section{8-20 December, 2020 Oxford, United Kingdom}

Table 1. Descriptive statistics

\begin{tabular}{|l|l|l|l|}
\hline Variables & Mean & Median & Standard Deviation \\
\hline GAAP_ETR & 0.202 & 0.212 & 0.076 \\
\hline CSRI & 0.354 & 0.338 & 0.132 \\
\hline SIZE & 18.842 & 19.678 & 1.924 \\
\hline ROE & 0.105 & 0.101 & 0.084 \\
\hline LEV & 2.163 & 1.457 & 2.085 \\
\hline CIR & 0.579 & 0.684 & 0.300 \\
\hline
\end{tabular}

According to Table 1, it shows that GAAP_ETR has a mean (median) value of 0.202 (0.212) on a scale of $0-1$. This indicates that overall, the effective tax rate in the Philippines is still low, which is around $20 \%$, while the prevailing corporate tax rate in the Philippines is $30 \%$. On the CSRI variable, the results of the observation show that the mean (median) value is 0.354 (0.338) on a scale of $0-1$. This indicates that the level of corporate social responsibility disclosure is considerably low because the disclosure is still in voluntary nature. The control variable of SIZE has a mean (median) of 18.842 (19.678), ROE has a mean (median) of 0.105 (0.101), LEV has a (median) of 2.163 (1.457) and CIR has a mean (median) of 0.579 (0.687).

Furthermore, Table 2 reports the correlation of the research variables using Pearson Correlation. The result shows that CSRI is positively associated with the GAAP_ETR. This indicates that the higher the level of social responsibility disclosure, the higher the effectivity of corporate tax rate or the lower the level of tax avoidance will be.

Table 2. Results of Pearson Correlation Test

\begin{tabular}{|l|c|c|c|c|c|c|}
\hline & GAAP_ETR & CSRI & SIZE & ROE & LEV & CIR \\
\hline GAAP_ETR & 1.000 & & & & & \\
\hline CSRI & & & & & & \\
\hline & $0.332^{* * *}$ & 1.000 & & & & \\
\hline SIZE & $(0.000)$ & & & & & \\
\hline & 0.059 & $-0.184^{*}$ & 1.000 & & & \\
\hline ROE & $(0.536)$ & $(0.051)$ & & & & \\
\hline & $0.526^{* * *}$ & $0.275^{* * *}$ & 0.017 & 1.000 & & \\
\hline LEV & $(0.000)$ & $(0.003)$ & $(0.859)$ & & & \\
\hline & $-0.221^{* *}$ & -0.130 & $0.283^{* * *}$ & 0.091 & 1.000 & \\
\hline CIR & $(0.019)$ & $(0.169)$ & $(0.002)$ & $(0.338)$ & & \\
\hline & $0.211^{* *}$ & $0.309^{* * *}$ & $-0.227^{* *}$ & 0.101 & $-0.548^{* * *}$ & 1.000 \\
\hline
\end{tabular}

$p$-values in parentheses ${ }^{*} p<0.1,{ }^{* *} p<0.05,{ }^{* * *} p<0.01$

The result of the second hypothesis testing shows that CSRI has an association with GAAP_ETR $(\beta=0.112, \mathrm{p}<0.05)$. A positive sign means that social responsibility disclosure 


\section{$11^{\text {th }}$ International Conference on Modern Research in}

MANAGEMENT, ECONOMICS and ACCOUNTING

\section{8-20 December, 2020 Oxford, United Kingdom}

positively correlates with tax effectiveness, thereby reducing tax avoidance practices. This finding remains consistent after including the year and the industry of the dummy variables. This means the hypothesis stating that social responsibility is positively associated with tax avoidance is not accepted. The finding of this study contradicts with the results of Preuss (2010) and David et al. (2015) studies, which stated that corporate social responsibility disclosure is positively associated with tax avoidance. Therefore, this shows that companies that actively disclose their social responsibility have a higher rate of effective tax, which means they have low rate of tax avoidance. The smaller the effective tax rate is, the greater the tax avoidance practice by the company will be. This condition shows that social responsibility disclosure is substantial, which means that social responsibility disclosure is a manifestation of ethical values adopted by the companies. Companies that adopt ethical values within the social responsibility are embraced as valuable by the companies in all aspects of its business. If social responsibility disclosure only acts as a symbol, thus the disclosure is limited to be a symbol or be an image of the company, so the company is seen as a responsible company in running its business practices, but does not enact it as a corporate value.

Table 3. Results of Hypothesis Test

\begin{tabular}{|l|c|c|}
\hline \multirow{2}{*}{ Variable } & Coeff. & Coeff. \\
\cline { 2 - 3 } & $(\boldsymbol{t}$-stat $)$ & $(\boldsymbol{t}$-stat $)$ \\
\hline CSRI & $0.112 * *$ & $0.154 * * *$ \\
\hline SIZE & $(2.35)$ & $(2.86)$ \\
\hline & $0.006 * *$ & $0.009 * *$ \\
\hline ROE & $(2.09)$ & $(2.37)$ \\
\hline & $0.457 * * *$ & $0.425 * * *$ \\
\hline LEV & $(6.32)$ & $(4.65)$ \\
\hline & $-0.011 * * *$ & $-0.011 * * *$ \\
\hline CIR & $(-3.26)$ & $(-3.10)$ \\
\hline & $-0.007 * *$ & 0.042 \\
\hline Year Dummy & $(-0.29)$ & $(1.27)$ \\
\hline Industry Dummy & & included \\
\hline F & & included \\
\hline Adj R & $14.750 * * *$ & $5.56 * * *$ \\
\hline
\end{tabular}

$p$-values in parentheses ${ }^{*} p<0.1,{ }^{* *} p<0.05,{ }^{* * *} p<0.01$

The result of the study implicates that stakeholders can use corporate social disclosure as a source of information to make decisions. Information on social responsibility disclosures can be taken into consideration in addition to the financial information. The result of the study indicates that information about social responsibility disclosure with a non-financial nature is associated with the financial information produced by the company, particularly in the aspect of taxation 


\section{$11^{\text {th }}$ International Conference on Modern Research in}

MANAGEMENT, ECONOMICS and ACCOUNTING

\section{8-20 December, 2020 Oxford, United Kingdom}

\section{Conclusion}

This study examines the association between social responsibility disclosure and tax avoidance in go public companies in the Philippines. The study shows that social responsibility disclosure is negatively associated with tax avoidance, which means that companies that actively disclose social responsibility are companies that have a low level of tax avoidance. This study shows a limitation because it only focuses on companies that disclose their social responsibility through sustainability reporting in accordance with the guidelines issued by GRI. Future studies can compare the association of social responsibility disclosure with different media disclosure of companies with other variables that describe ethical behaviour or corporate fraud. The research scope will need to be expanded by covering other developing countries, so that it can give a comprehensive picture about social responsibility disclosure practices and corporate ethical behaviours. Research on developing countries can provide different results due to its different context with developed countries, thus it can enrich the study of corporate social responsibility disclosure. In addition, future research can add new variables that will moderate the relationship between social responsibility disclosure and corporate ethical behaviours.

\section{Acknowledgment (TNR 12pt. bold)}

This research was financially supported by the Directorate of Research and Development of Ministry of Research, Technology and Higher Education of the Republic of Indonesia

\section{References (TNR 14pt., bold)}

Atkins, B. (2006). Corporate Social Responsibility: Is It "Irresponsibility"? The Corporate Governance Advisor, 14(6), 28-29.

Bowen, H. R. (1953). Social Responsibilities of the Businessman. New York: Harper \& Row.

Blazovich, J., and Smith, L. M. (2011). Ethical Corporate Citizenship: Does it Pay? Research on Professional Responsibility and Ethics in Accounting 15, 127-163.

Carroll, A. B. (1979). A Three-Dimensional Conceptual Model of Corporate Performance. Academy of Management Review, 4(4), 497-505.

Davis, A., K., David, A. G., Krull, L. K., and Williams, B. M. (2015) Do Socially Responsible Firms Pay More Taxes? The Accounting Review 91(1): 47-68.

Desai, M. A., and Dharmapala, D. (2006). Corporate tax avoidance and high-powered incentives. Journal of Financial Economics, 79(1), 145-179.

Dhaliwal, D., Gleason, C., and Mills, L. (2004). Last-chance earnings management: using the tax expense to meet analysts' forecasts. Contemporary Accounting Research 21, 431-459.

Elkington, J. (1998). Accounting for the Triple Bottom Line. Measuring Business Excellence 2(3), 18-22. 
$11^{\text {th }}$ International Conference on Modern Research in MANAGEMENT, ECONOMICS and ACCOUNTING

\section{8-20 December, 2020 Oxford, United Kingdom}

Garriga, E., and Melé, D. (2004). Corporate social responsibility theories: Mapping the territory. Journal of Business Ethics, 53(1-2), 51-71.

Goel, P. (2010). Triple Bottom Line Reporting: An analytical Approach for Corporate Sustainability. Journal of Finance, Accounting and Management, 1(1), 27-42.

Grougiou, V., Dedoulis. E., and Leventis, S. (2016). Corporate Social Responsibility Reporting and Organizational Stigma: The Case of "Sin" Industries. Journal of Business Research, 69(2), 905-914.

Harjoto, M. A., and Jo, H. (2011). Corporate Governance and CSR Nexus. Journal of Business Ethics, 100(1), 45-67.

Hemingway, C., and Maclagan, P. (2004). Managers' Personal Values as Drivers of Corporate Social Responsibility. Journal of Business Ethics,50(1), 33-44.

Hoi, C. K., Wu, Q., and Zhang, H. (2013). Is Corporate Social Responsibility (CSR) Associated with Tax Avoidance? Evidence from Irresposible CSR Actitivies. The Accounting Review, 88(6), 2025-2059.

Mohanadas, N. D., Abdullah Salim, A. S., and Pheng, L. K. (2019). CSR and tax aggressiveness of Malaysian listed companies: evidence from an emerging economy. Social Responsibility Journal, 16(5), 597-612. https://doi.org/10.1108/SRJ-01-2019-0021

Lanis R., and Richardson, G. (2012) Corporate Social Responsibility and tax Agressiveness: An Empirical Analysis. Journal of Accounting and Public Policy 31(1), 86-108

Lanis, R., and Richardson, G. (2015). Is Corporate Social Responsibility Performance Associated with Tax Avoidance? Journal of Business Ethics, 127, 1-19.

Lev, B., Petrovits, C., and Radhakhrisnan, S. (2010). Is Doing Good Good for You? How Corporate Charitable Contributions Enhance Revenue Growth. Strategic Management Journal 31(2): 182-200.

Lietz, G. M. (2013). Tax Avoidance vs Tax Aggressiveness: A Unifying Conceptual Framework. Journal Institute of Accounting and Taxation: Munster School of Business and Economics.

Ling, T. C., and Sultana, N. (2015). Corporate Social Responsibility: What Motivates Management to Disclose? Social Responsibility Journal, 11(3), 513-534.

Orlitzky, M., Schmidt, F.L. and Rynes, S.L. (2003). Corporate social and financial performance: A meta-analysis. Organization studies, 24(3), 403-441.

Preuss, L. (2010). Tax Avoidance and Corporate Social Responsibility: You Can't Do Both, or Can You? Corporate Govenance 10(4), 365-374.

Prior, D., Surroca, J., and Tribó, J. A. (2008). Are socially responsible managers really ethical? Exploring the relationship between earnings management and corporate social responsibility. Corporate Governance, 16(3), 160-177. https://doi.org/10.1111/j.14678683.2008.00678.x 
$11^{\text {th }}$ International Conference on Modern Research in

MANAGEMENT, ECONOMICS and ACCOUNTING

18-20 December, 2020 Oxford, United Kingdom

Richardson, G. (2008). The relationship between culture and tax evasion across countries; Additional Evidence and Extensions, Journal of International Accounting, Auditing, and Taxation, 17, 67-78.

Sikka, P. (2010) Smoke and Mirrors: Corporate Social Responsibility and Tax Avoidance. Accounting Forum 34(3-4), 153-168.

Wang, Q., Dou, J., and Jia, S. (2015). A Meta-Analytic Review of Corporate Social Responsibility and Corporate Financial Performance; The Moderating Effect of Contextual Factors. Business and Society, 55(8), 1083-1121.

Watson, L. (2015) Corporate Social Responsibility, Tax Avoidance, and Earnings Performance. The Journal of the American Taxation Association 37(2), 1-21. 